INTERNATIONAL JOURNAL OF RESEARCHES IN BIOSCIENCES, AGRICULTURE AND TECHNOLOGY (C) VISHWASHANTI MULTIPURPOSE SOCIETY (Global Peace Multipurpose Society) R. No. MH-659/13(N) www.vmsindia.org

\title{
STUDY OF DESITY AND MOLAR VOLUME OF LITHIUM ION BASED GLASSES
}

\author{
A. Lad and D. Dongare \\ Amolakchand Mahavidyalaya Yavatmal \\ drajay_lad@rediffmail.com
}

\begin{abstract}
:
The Lithium ion based glasses of composition 30Li $2 \mathrm{O}:(70-\mathrm{x}) \mathrm{B}_{2} \mathrm{O}_{3}: \mathrm{xAl}_{2} \mathrm{O}_{3}(\mathrm{x}=0,5,10,15,20,25)$ were prepared by melt quenching technique. Density of the glasses was determined by using Archimedes principle \& molar volume of glass has determined by using molar mass and density. It was found that density of glasses increased while their molar volume values decreases. The values of number of ions per $\mathrm{cm}^{3} \mathrm{were}$ reported from density. Keywords - Density; Molar volume; mixed glass former effect
\end{abstract}

\section{Introduction:}

The physical properties of glasses are of great interest because of their wide range of applications in science, industries and many allied areas. The density and molar volume important physical properties of glasses In borate glasses $\mathrm{B}_{2} \mathrm{O}_{3}$ is fundamental glass former because of its higher bond strength, lowercasing size, small heat of fusion and trivalent nature of $\mathrm{B}$, in which $\mathrm{B}^{3+}$ ions are triangularly coordinated by oxygen and corner bonded in random configuration[1]. Borate glasses containing $\mathrm{Li}^{+}$ ions are considered to be potential candidates of for electrolytes of thin film batteries as they exhibit isotropic ion conductivity and stability at high voltage [2]. The Density and molar volume have investigated in transition metal ion glasses[3]. The structure of glasses with composition $\mathrm{XB}_{2} \mathrm{O}_{3}-(1-\mathrm{x}) \mathrm{M}_{2} \mathrm{O}(\mathrm{M}=\mathrm{Li}, \mathrm{Na}, \mathrm{K})$ consist $\mathrm{B}-\mathrm{O}$ network built up from planner three coordinate \& tetra-hydral four coordinate B atom[4]. High valence cations such as $\mathrm{Al}+3$ are commonly used as intermediate species[5].Jen and Kalinosky[6] suggested model for describing bridging to non bridging oxygen ratio as a function of the glass composition and calculated values of glass density based on this model.

In this work an attempts has been made for preparation and structural investigation of the glasses has been studied with the help of density and molar volume measurement.

\section{Experimental:}

The lithium ion based glasses $30 \mathrm{Li}_{2} \mathrm{O}:($ $70-\mathrm{x}) \mathrm{B}_{2} \mathrm{O}_{3}: \mathrm{xAl}_{2} \mathrm{O}_{3} \quad(\mathrm{x}=0,5,10,15,20,25)$ were prepared by conventional melt-quenching technique. As a starting material $\mathrm{Li}_{2} \mathrm{CO}_{3}, \mathrm{~B}(\mathrm{OH})_{3}$ and $\mathrm{Al}_{2} \mathrm{O}_{3}$ of $\mathrm{AR}$ grade, Merc laboratory were used. These chemicals were thoroughly mixed and ground for 20-30 min. in mortar pastel and then $10 \mathrm{gm}$ was melted in alumina crucible using muffle furnace for 4-5 Hrs at temperature ranging from $800-1100^{\circ} \mathrm{C}$. When melt was thoroughly homogenized and attained desirable viscosity, it was poured into metal plate. The prepared glass was annealed at appropriate temperature at $200^{\circ} \mathrm{C}$.

Density was measured for all samples at room temperature using Benzene as immersion liquid. Density is generally measured by the fluid displacement method depending on Archimedes principle. The density was obtained by employing the relation

$\rho=W_{\mathrm{a}} \rho_{\mathrm{b}} /\left(\mathrm{W}_{\mathrm{a}}-\mathrm{W}_{\mathrm{b}}\right)$

Where $\mathrm{W}_{\mathrm{a}}$ be Weight of glass in air, $\mathrm{W}_{\mathrm{b}}$ be Weight of glass sample in buoyant liquid,

$\left(\mathrm{W}_{\mathrm{a}}-\mathrm{W}_{\mathrm{b}}\right)$ is buoyancy and $\rho_{\mathrm{b}}$ density of benzene liquid.

By using molecular weight of glass sample and density, molar volume of the glass samples can be calculated from following relation $\mathrm{V}_{\mathrm{m}}=\mathrm{M} / \rho$

$\mathrm{V}_{\mathrm{m}}$ is molar volume. $\mathrm{M}$ is molecular weight of sample and $\rho$-density of the sample

Table.1 : Compositions of glasses ,Molar volumes \& density of glasses

\begin{tabular}{|l|l|l|l|l|l|l|}
\hline $\mathrm{S}^{*}$ & $\begin{array}{l}\text { Mole } \\
\% \quad \text { of } \\
\mathrm{Li}_{2} \mathrm{O}_{3}\end{array}$ & $\begin{array}{l}\text { Mole } \\
\% \quad \text { of } \\
\mathrm{B}_{2} \mathrm{O}_{3}\end{array}$ & $\begin{array}{l}\text { Mole of } \\
\% \text { of } \\
\mathrm{Al}_{2} \mathrm{O}_{3}\end{array}$ & $\begin{array}{l}\text { Molar } \\
\text { volume( } \\
\left.\mathrm{V}_{\mathrm{m}}\right)\end{array}$ & $\begin{array}{l}\mathrm{D}^{*} \\
(\rho)\end{array}$ & $\begin{array}{l}\text { Ions per } \\
\mathrm{cm}^{3} \\
\left(10^{22}\right)\end{array}$ \\
\hline 1 & 30 & 70 & 0 & 24.9997 & 2.30 & 2.4 \\
\hline 2 & 30 & 65 & 5 & 24.4329 & 2.42 & 2.465 \\
\hline 3 & 30 & 60 & 10 & 24.1926 & 2.52 & 24.898 \\
\hline 4 & 30 & 55 & 15 & 23.894 & 2.62 & 2.52 \\
\hline 5 & 30 & 50 & 20 & 23.7894 & 2.69 & 2.53 \\
\hline 7 & 30 & 45 & 25 & 23.6567 & 2.81 & 2.5467 \\
\hline
\end{tabular}

$\mathrm{S}^{*}=$ Sample; $\mathrm{D}^{*}=$ Density

\section{Result and Discussion:}

The calculated values of density and molar volume for all samples have been displayed in table 1 . The variation of density and molar volume with $\mathrm{Al}_{2} \mathrm{O}_{3}$ is mole \% for all glass samples is shown in fig 1-2. The value of density increased while the value of molar volume decreases with gradually increases of 
$\mathrm{Al}_{2} \mathrm{O}_{3}$ content in lithium borate glasses. The density of the glass is the volume of the constituent ions and it depends of nature, the number of ions and the way by which ions can enter the glass structure[7].In lithium borate glasses introduction of $\mathrm{Al}_{2} \mathrm{O}_{3}$ along with $\mathrm{B}_{2} \mathrm{O}_{3}$ hence it is mixed glass former effect on density and molar volume [8].The values of number of ion per $\mathrm{cm}^{3}$ is reported on the basis of molar volume.

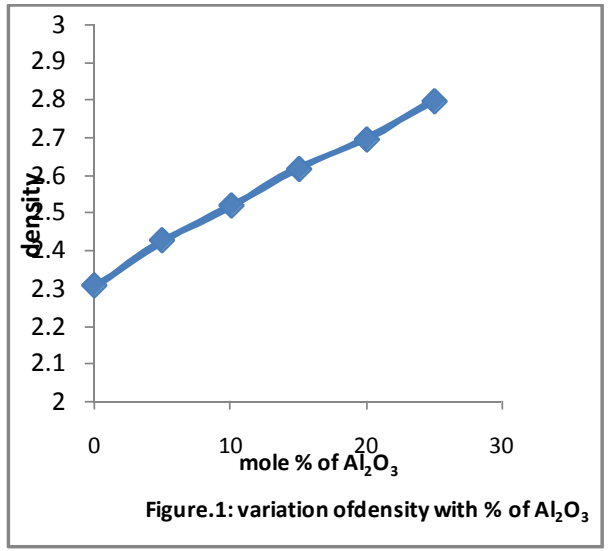

\section{References:}

(1) S.G. Motke, S.P. Yawale; Bull. Material.Sci. 25(1) (2002)75.

(2) Young - II Lee etals solid state ionics 175(2004) 687

(3) Ghose A. etals; Bull Matter. Sci. 18(1) pp.53-60

(4) J. Wong, C.A. Angell; glass

\section{Conclusion:}

The density of glasses increased while their molar volume decreases with the increase of Aluminum oxide in lithium borate glasses. All above conclusion are in complete agreement with experimental results obtained

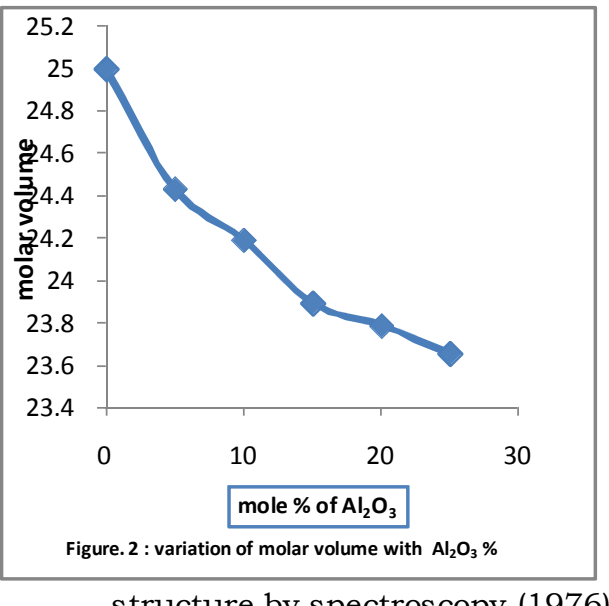

(5) J. Mauro Report from ; Glass Laboratory, College of ceramics, Alfred university (2000)

(6) J.S. Jen et a1.; Journal of non crystalline solids, 38(3) 21-26(1980)

(7) J.M. stevels; electrical properties of glass, W1, 20 springer Berlin(1957)

(8) R. Christersen J. Byer; European journal of Glass science and technology, part B, 50(4) 